\title{
POPULATION STRUCTURE OF THE DEEP SEA HERMIT-CRAB Catapaguroides microps (PAGUROIDEA, ANOMURA) IN THE CAMPOS BASIN, RJ, BRAZIL*
}

\author{
Luana S. F.Lins ${ }^{1, * *}$ and Tarso Costa ${ }^{2}$
}

${ }^{1}$ Universidade Federal do Rio de Janeiro, Museu Nacional, Departamento de Invertebrados (Quinta da Boa Vista, 20940-040 Rio de Janeiro, RJ, Brasil)

${ }^{2}$ Universidade Federal Fluminense - UFF

Universidade Federal Fluminense, Programa de Pós-Graduação em de Biologia Marinha (Campus do Valonguinho, Caixa Postal 100644, 24001-970 Niterói, RJ, Brasil)

** Corresponding author: lins_luana@yahoo.com.br

\section{A B S T R A C T}

The population of Catapaguroides microps A. Milne-Edwards and Bouvier, 1892 in the Campos Basin was studied with an emphasis on its composition in the Northern and Southern parts of the Basin, the different gender sizes, sex ratio, and size class distribution. Specimens were collected under the "Program for the Environmental Characterization of the deep waters of the Campos Basin" ("Programa de Caracterização Ambiental das Águas Profundas da Bacia de Campos") in February and August 2003. A total of 339 hermit crabs were analyzed. Individual abundance was higher in the North. C. microps shows sexual dimorphism for body size, the males being larger than the females. The sex ratio is skewed in the female's favor (1:0.7), as shown by previous studies on shallow-water populations.

\section{RESUMO}

A população de Catapaguroides microps A. Milne-Edwards and Bouvier, 1892 da foi analisada com foco na abundância de indivíduos, diferença de tamanho entre machos e fêmeas, razão sexual e distribuição dos indivíduos nas classes de tamanho, ao norte e ao sul da Bacia de Campos. As amostras foram coletadas pelo Programa de Caracterização Ambiental da Bacia de Campos em fevereiro e agosto de 2003. O total de indivíduos analizados foi de 339. A abundância foi maior no norte da Bacia de Campos. Catapaguroides microps mostrou dimorfismo sexual no tamanho do corpo, sendo os machos maiores que as fêmeas. A razão sexual favorece as fêmeas $(1: 0,7)$, de forma similar a outros estudos efetuados com populações de águas rasas.

Descriptors: Decapoda, Paguridae, Southwest Atlantic, Population biology, Sex ratio.

Descritores: Decapoda, Paguridae, Atlântico sudoeste, Biologia populacional, Razão sexual.

\section{INTRODUCTION}

Species of superfamily Paguroidea are distributed in six families. Typically, they use mollusk shells to protect their soft abdomen; their fifth pereopod is reduced and their body has a hermit-crab shape. Almost all 800 species of hermit crab are mobile while sheltered. The combination of mobility and protection afforded by this life-style must contribute to the success of this taxon found in large numbers in all marine environments, including tropical shores (HAZLETT, 1981). Most species of hermit crab are omnivores or detritivores (ORTON, 1927; HAZLET, 1981). Hermit-crabs show intense competition. Males compete for the access to females but the competition is particularly intense for the acquisition of shells (ASAKURA, 1995; TURRA; LEITE, 2000).

(*) Paper presented at the $2^{\text {nd }}$ Brazilian Congress of Marine Biology, on 24-28 May. Búzios, RJ, Brazil. 2009.
Whereas species of hermit-crabs inhabiting coastal environments are well known for their population biology, knowledge of deep-sea populations is sparse. Studies in shallow-waters have shown a tendency to an unbalanced sex-ratio, with a dominance of females. Males are usually larger than females (FRANSOZO; MATELLATO, 1998; MANTELLATO et al., 2005; MANJÓN-CABEZA; GARCÍA-RASO, 1998; ASAKURA, 1995; TURRA; LEITE, 2000).

Catapaguroides microps A. Milne-Edwards and Bouvier, 1892 has a cosmopolitan distribution, having been recorded in the Eastern Atlantic, i.e., in the Azores, the Canary Islands, at Cape Finisterre (Spain) and in Morocco; and in Indo-Pacific Indonesia (SAINT LAURENT, 1967). This is the only species of the genus to have been recorded in the southwestern Atlantic. The objectives of this study were: (1) to compare the abundance of $C$. microps as between the North and South of the Campos Basin, Brazil; (2) to 
test whether males are bigger than females as shown in other studies; (3) to test whether the sex-ratio is $1: 1$, and (4) to analyze size-class distribution in the populations analyzed.

\section{Material AND Methods}

\section{Study area}

The study area is the continental slope of the Campos Basin, RJ $\left(21^{\circ} 48^{\prime} \mathrm{S} / 22^{\circ} 48^{\prime} \mathrm{S}\right)$, the most important oil-producing region in Brazil, accounting for $70 \%$ of all Brazilian oil production; biodiversity there may be menaced by this activity. The Brazilian continental slope is $120-150 \mathrm{~km}$ wide and its maximum depth is of 2,400 to $3,000 \mathrm{~m}$ (SOARESGOMES et al., 1999). The hydrodynamic regime in the region is controlled by the Brazil current, which flows parallel to the coastline, as far down as $200 \mathrm{~m}$, transporting the water mass called Tropical Water. Below $300 \mathrm{~m}$ depth, the current changes its direction and is called the Brazil counter-current. This current transports the water mass called South Atlantic Central Waters (PETROBRAS, 2003).

\section{Sampling and Laboratory}

The sampling was carried out under the "Program for the Environmental Characterization of Deep Water of the Campos Basin" ("Programa de Caracterização Ambiental das águas Profundas da Bacia de Campos (Cenpes/Petrobras)"). Two sampling expeditions were undertaken in February 2003 (Oceanprof I) and August 2003 (Oceanprof II) using trawling nets. Eighteen sites were sampled, nine in the south and nine in the north of the Campos basin, three at each depth $(1100 \mathrm{~m}, 1300 \mathrm{~m}$ and $1600 \mathrm{~m})$.

Specimens were fixed in $70 \%$ ethanol. The shells were removed, sex determined, and cephalic shields (CS) measured under the stereoscopic microscope with an ocular lens with a millimetric grid. The specimens were deposited in the Crustacean Collection of the Museu Nacional, Rio de Janeiro (MNRJ).

\section{Statistical Analysis}

CPUE (Capture per Unit Effort) analysis was employed to compare the respective abundance in the South and North of the Campos basin. The specific trawling distance of $1000 \mathrm{~m}$ was used; CPUE was calculated for each depth interval of $50 \mathrm{~m}$.

Mann-Whitney $\mathrm{U}$ tests were used to test the difference between sexes of CS $(\alpha=0.05)$ and the Chi-square tests were used to analyze the sex-ratios and size classes $\left(\mathrm{H}_{0}=1: 1, \alpha=0.05\right)$.

\section{RESULTS}

A total of 339 individuals were collected, 23 of them in the southern portion of the Campos Basin. The CPUE analysis showed that more individuals were sampled in the North than in the South of the Basin. The highest CPUE value was found in the North (9.05 ind $/ 1000 \mathrm{~m}$ ) at the depth of around $1100 \mathrm{~m}$ while the highest value found in the South was $0.44 \mathrm{ind} / 1000 \mathrm{~m}$ at the depth of $1300 \mathrm{~m}$ (Fig. 1).
A

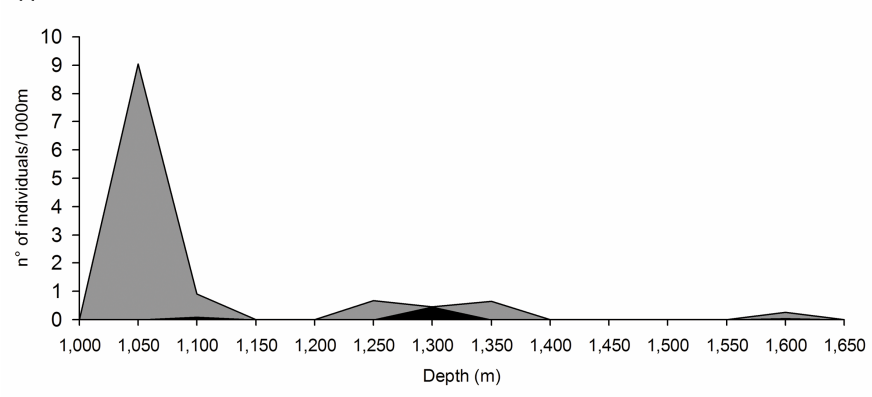

B

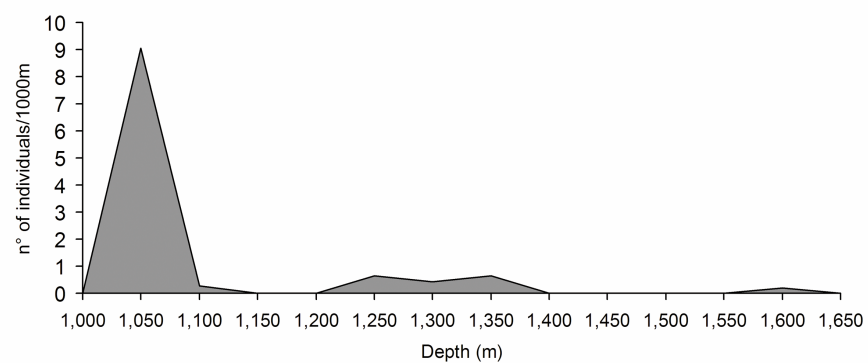

Fig. 1. A, CPUE values of Catapaguroides microps showing that density is higher in the North than in the South of Campos Basin; B, CPUE values showing a higher density at the depth of $1100 \mathrm{~m}$. 
Males had a longer CS than the females $(\mathrm{Z}=$ 5.39; $<<0.01$ ) (Fig. 2); the sex-ratio was $0.7: 1$, biased towards the females $\left(\chi^{2}=9.6 ; \mathrm{df}=1 ; \mathrm{p}<0.05\right)$. The sex-ratio was biased in three intermediate size classes and in the last four classes ( $<$ 0.05) (Fig. 3).
There were more females in the smaller classes and more males in the larger classes. Brooding females were more abundant in size classes 1.5-2.0 $\mathrm{mm}$ and males in size classes 2.1- $2.7 \mathrm{~mm}$. Individuals with CS smaller than $1.4 \mathrm{~mm}$ were rare (Fig. 4).

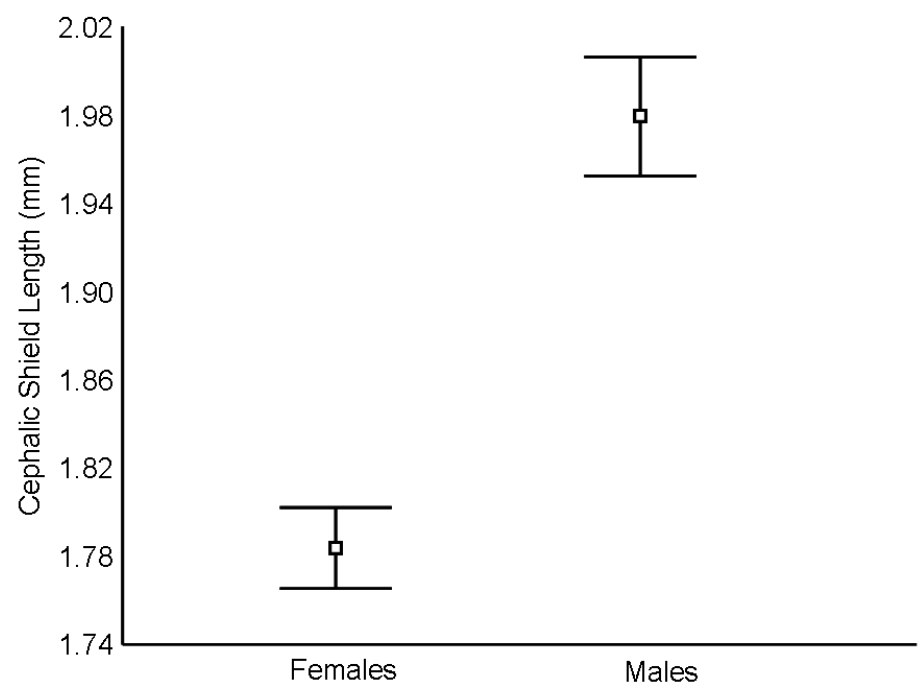

Fig. 2. Box Plot graph showing that size (cephalic shield) is longer in males than in females in Campos Basin. The bars are the standard errors and the squares are the means.

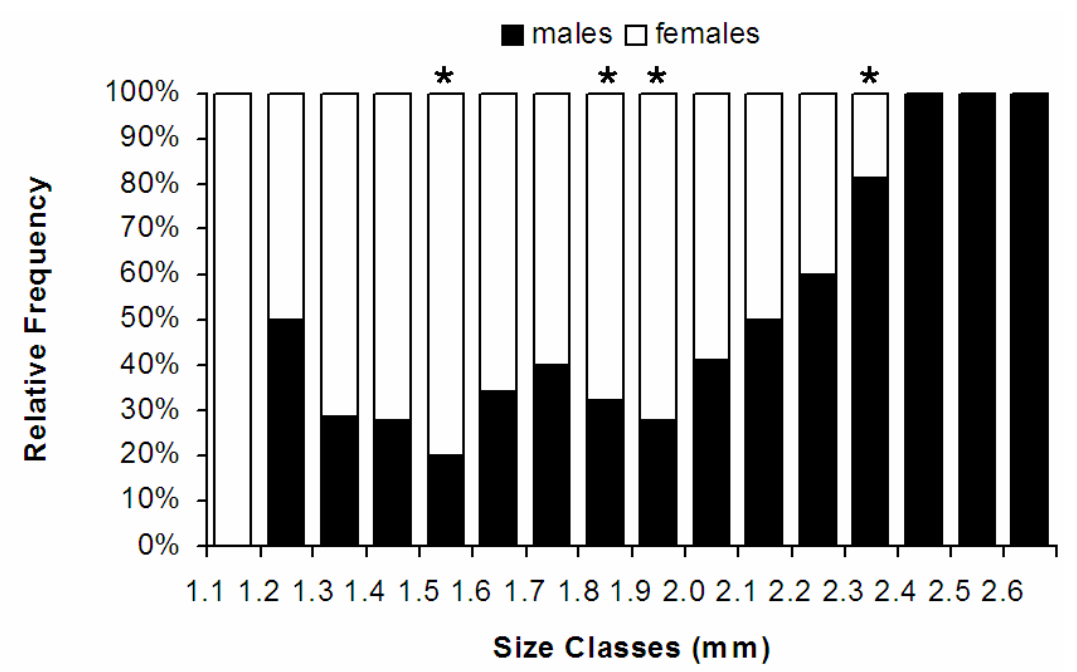

Fig. 3. Sex ratio for size class of Catapaguroides microps in Campos Basin. The symbol * denotes a significant difference from $1: 1$. 


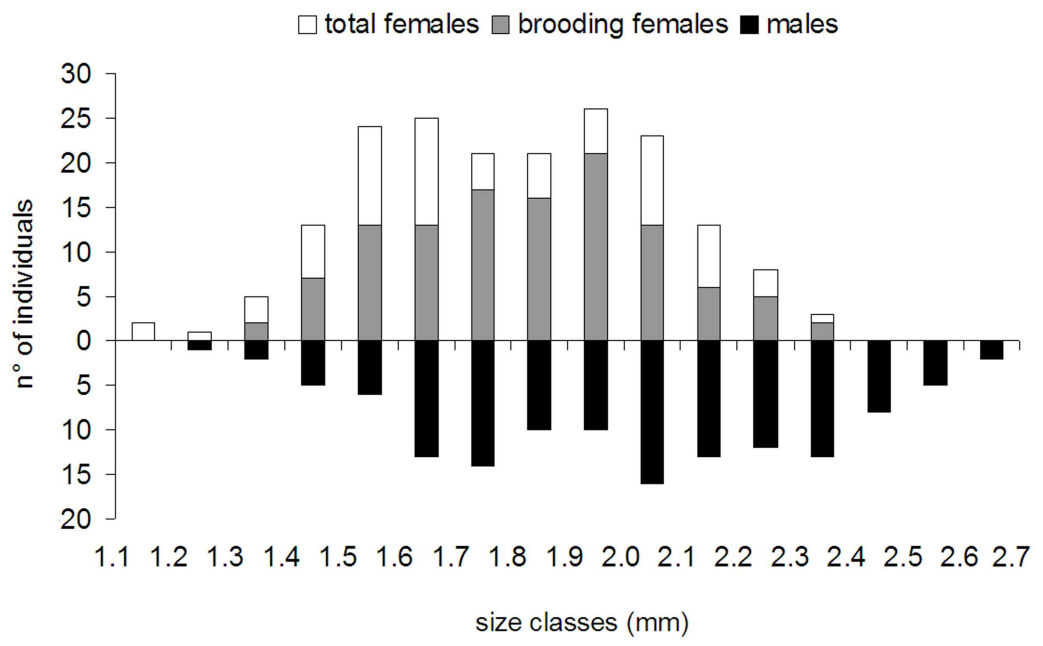

Fig. 4. Size class distribution of Catapaguroides microps showing that males are more abundant in the bigger size classes and that abundance is lower in the smaller size classes.

\section{Discussion}

We found that there was a higher density of individuals in the Northern region of the Campos Basin, but this result cannot be clearly understood with just the samples made in this study. The first possible explanation is that this population might be a unique population with a higher concentration in the North with fewer individuals of this same population reaching the South. Another possible explanation is that there are two different populations of $C$. microps occurring in the Campos Basin, a larger one in the North and another much smaller one in the South. Catapaguroides microps is sexually dimorphic in relation to size, with males reaching larger shield lengths than females. A similar growth pattern has been observed in populations of shallow water hermitcrabs such as those of Calcinus tibicen (FRANSOZO; MANTELATTO, 1998), Dardanus insignis (BRANCO et al., 2002), and Pagurus brevidactylus (MANTELATTO et al., 2005) studied in São Paulo, and Diogenes puligator (MAJÓN-CABEZA; GARCIA-RASO, 1998) in the Strait of Gibraltar. Above the $2.2 \mathrm{~mm} \mathrm{CS}$, males become more abundant (Fig. 3), suggesting a higher growth rate or a longer growth period for males; females possibly allocate a larger amount of energy to reproduction rather than to growth (DÍAZ; CONDE, 1989, FRANSOZO; MANTELATTO, 1998).

A sex ratio skewed in the females' favor, as observed in C. microps, seems to be a general pattern among crustaceans, being the rule rather than an exception (WENNER, 1972; COSTA; SOARESGOMES, 2009). Other studies of shallow-water hermit crabs found a similar population pattern (DÍAZ; CONDE, 1989, FRANSOZO; MANTELATTO, 1988, BRANCO et al., 2002, WADA 1999, ASAKURA, 1995). ASAKURA (1995), studying hermit crabs in the laboratory, observed a 1:1 sex ratio, and suggested that the females predominate under natural conditions because males have higher mortality due to their more intense competition for shells and mates.

A smaller number of individuals was found in the smaller size classes $(<1.4 \mathrm{~mm}$ CS $)$ supporting the hypothesis of FRANSOZO; MANTELATTO (1998) that recruitment occurs in a different habitat from that occupied by the adults.

In this study, it was found that the deep sea Catapaguroides microps has a similar population structure to that of the shallow-water hermit crab species hitherto studied in Brazil. This might suggest that deep-sea hermit crabs populations are subject to the same environmental pressures as the shallow-water populations; the interactions between individuals having more influence than other factors.

\section{ACKNOWLEDGMENTS}

We thank Petrobras/Cenpes for providing the deep sea samples and FAPERJ for the grant for this study. We are grateful to Prof. Rafael Lemaitre for his help with the identification. We would also thank our laboratory colleagues at the Museu Nacional-RJ and the Universidade Federal do Rio de Janeiro, Instituto de Biologia for participating in the discussion of this study. We are grateful also to Guilherme Muricy and the anonymous referee who revised the manuscript. 


\section{REFERENCES}

ASAKURA, A. Sexual differences in life history and resource utilization by the hermit crab. Ecology, v. 76, n. 7, p. 2295-2313, 1995.

BRANCO, J. O.; TURRA, A.; SOUTO, F. X. Population biology and growth of the hermit crab Dardanus insignis at Armação do Itapocoroy, southern Brazil. J. Mar. Biol. Ass. UK, v. 82, p. 597-603, 2002.

COSTA, T.; SOARES-GOMES, A. Population structure and reproductive biology of the fiddler crab Uca rapax (Decapoda, Ocypodidae) in a tropical coastal lagoon, Southeast Brazil. Rev. Bras. Zool., v. 26, n. 4 p. 647-657.

DE SAINT LAURENT, M. Révision des genres Catapaguroides et Cestopagurus et description de quatre genres nouveaux I. Catapaguroides Bouvier (Crustacés Decápodes Paguridae). Bull. Mus. Na.t His. Nat., s. 2, v. 39, n. 5, p. 923-954, 1967.

DIAZ, H.; CONDE, J. E. Population dynamics and life history of the mangrove crab Aratus pisonii (Brachyura: Grapsidae) in a marine environment. Bull. Mar. Sci. v. 45, n.1, p. 148-163, 1989.

FRANSOZO, A.; MANTELATTO, F. L. M. Population structure and reproductive period of the tropical hermit crab Calcinus tibicen (Decapoda: Crustacea: Diogenidae) in the region of Ubatuba, São Paulo, Brazil. J. Crust. Biol., v. 18, n. 4, p. 738:745, 1998.

HAZLETT, B. A. The behavioral ecology of hermit crabs. Ann. Rev. Ecol. Syst., v. 12, p. 1-22, 1981.

MANJÓN-CABEZA, M. E.; GARCÍA-RASO, J. E. Population structure and growth of the hermit crab Diogenes puligator (Decapoda: Anomura: Diogenidae) from the Northeastern Atlantic. J. Crust. Biol., v. 18, n. 4, p. 753-762, 1998.
MANTELATTO, F. L.; CHRISTOFOLETTI, R. A.; VALENTI, W. C. Population structure and growth of hermit crab Pagurus brevidactilus (Anomura: Paguridae) from the Northern coast of São Paulo, Brazil. J. Mar. Biol. Ass. UK, v. 85, p. 127-128, 2005.

ORTON, J. H. On the mode of feeding of hermit-crab, Eupagurus bernhardus, and some other Decapoda. J. Mar. Biol. Ass. UK, v.14, n. 4, p. 909-9221, 1927.

PETROBRAS. Monitoramento Ambiental da Atividade de Perfuração de Poços de óleo e Gás na Bacia de Campos. Petróleo Brasileiro S.A. p. 1-89. 2003.

SOARES-GOMES, A.; ABREU, C. M. R. C.; ABSHER, T. M.; FIGUEIREDO, A. G. Abiotic features and the abundance of macrozoobenthos of continental margin sediments of East Brazil. Mar. Ecol. Pro. Ser., v. 127, p. 113-119, 1999.

TURRA, A.; LEITE, F. P. P. Population biology and growth of three sympatric intertidal hermit crabs in south-eastern Brazil. J. Mar. Biol. Ass. UK, v. 80, p. 1061-1069, 2000.

WENNER, A. M. Sex ratio as a function of size in marine Crustacea. Amer. Nat., v. 106, n. 949, p 321-349, 1972.

WADA, S. Enviromental factors affecting sexual size dimorphism in the hermit crab Pagurus middendorffii. J. Mar. Biol. Ass. UK, v. 79, p. 953-954, 1999.

(Manuscript received 04 June 2009; revised 09 November 2009; accepted 20 May 2010) 